\title{
Thiocyanate Measurement
}

National Cancer Institute

\section{Source}

National Cancer Institute. Thiocyanate Measurement. NCI Thesaurus. Code C154745.

The determination of the amount of thiocyanate present in a sample. 